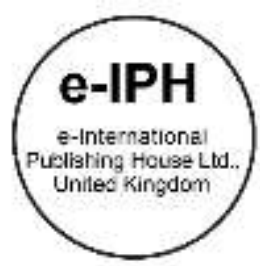

\title{
Addressing Offshore Tax Evasion Challenges in the Rising of Digitalization Economy
}

\author{
Nadia Omar ${ }^{12}$, Wan Liza Md Amin ${ }^{13}$, Nurazlina Abdul Raof ${ }^{12}$ \\ ${ }^{1}$ Faculty of Law, Universiti Teknologi MARA, Shah Alam, Malaysia \\ ${ }^{2} \mathrm{Ph} . \mathrm{D}$. Candidate, International Islamic University Malaysia, Gombak, Malaysia \\ ${ }^{3}$ Faculty of Law University of Edinburgh Scotland, United Kingdom \\ nadiaomar@uitm.edu.my, wanliza@uitm.edu.my,nurazlina@uitm.edu.my \\ Tel: 60163111078
}

\begin{abstract}
Countries worldwide have lost billions of dollars in tax revenue due to tax evasion on income from offshore bank accounts. The increasing challenge in a rising digital economy, has brought about significant economic and social disruption, necessitating advanced measures to combat offshore tax evasion. Hence, this paper aims to provide an overview and critical analysis of the digital approaches taken globally to curb offshore tax evasion strategies used by individual and multinational corporations. This paper employs library-based doctrinal study and comparative legal analysis in a descriptive, analytic provision, and prescriptive manner.
\end{abstract}

Keywords: Offshore Asset, Tax Evasion, Digital Economy, Law Reform

eISSN: 2398-4287C 2021. The Authors. Published for AMER ABRA cE-Bs by e-International Publishing House, Ltd., UK. This is an open access article under the CC BYNCND license (http://creativecommons.org/licenses/by-nc-nd/4.0/). Peer-review under responsibility of AMER (Association of Malaysian Environment-Behaviour Researchers), ABRA (Association of Behavioural Researchers on Asians/Africans/Arabians) and cE-Bs (Centre for Environment-Behaviour Studies), Faculty of Architecture, Planning \& Surveying, Universiti Teknologi MARA, Malaysia.

DOI: https://doi.org/10.21834/ebpj.v6i18.3019

\subsection{Introduction}

Evading taxes through offshore bank accounts is the most common way for tax evaders in the international landscape. Countries worldwide have lost billions of dollars in tax revenue due to tax evasion on income from offshore bank accounts. The Tax Justice Network (2021) reports that countries globally lose over USD427 billion in tax every year. Out of this global loss, Malaysia experienced USD1,378,671,123 loss each year, which is equivalent to USD45 per member of the population. Of this amount in tax lost each year to tax havens, the report shows that USD1 billion is directly lost to corporate tax abuse by multinational corporations and private tax evasion. Private tax evaders paid less tax than they should have by sheltering their financial assets offshore, causing Malaysia to lose USD330 million.

Disparities in tax law systems across foreign countries encourage even more cross-border tax evasion. Indeed, the fight against offshore tax evasion remains a significant challenge for all governments. However, the methods by which governments enforce the tax laws and by which individuals and firms evade their taxes change over time, due at least in part to changing technology (Alm, 2021). Without a comprehensive reform on local regimes, offshore tax evasion activities could not be curbed, and a government would be at high risk of losing its revenue. The increased priority to combat tax evasion necessitates the thoughtful reassessment of existing legal frameworks and enforcement methods to determine their efficacy in tackling this financial crime. In addition, the government needs to keep pace with the fast changes occurring in the digital economy. However, despite this fundamental change globally to previous enforcement practice, academic legal studies have not kept up with the developments in this area. Scholarly attention to the law on this

eISSN: 2398-4287@ 2021. The Authors. Published for AMER ABRA cE-Bs by e-International Publishing House, Ltd., UK. This is an open access article under the CC BYNCND license (http://creativecommons.org/licenses/by-nc-nd/4.0/). Peer-review under responsibility of AMER (Association of Malaysian Environment-Behaviour Researchers), ABRA (Association of Behavioural Researchers on Asians/Africans/Arabians) and CE-Bs (Centre for Environment-Behaviour Studies), Faculty of Architecture, Planning \& Surveying, Universiti Teknologi MARA, Malaysia.

DOI: https://doi.org/10.21834/ebpj.v6i18.3019 
financial crime in Malaysia has largely been a relatively new phenomenon. Therefore, this study analyses ways to curb such activities by analyzing effective digital countermeasures adopted by leading jurisdictions, i.e., the United Kingdom (U.K.) and the United States of America (USA). (Storm et al., 2018).

Our focus is on the initiatives and development of digital approaches in controlling offshore tax evasion in the USA, the U.K., and Malaysia. Our study concludes that solid and effective tax regimes play an essential role in mitigating offshore tax evasion in these countries. Adopting digital approaches is crucial to getting an impactful result. The paper is organized as follows. In the next section, we highlight the purpose and objective of the study. In section 2, we gather the relevant literature reviews. The method used for data collection is discussed in the next section. In sections 4 and 5 , we highlight and discuss the findings. In the end, this paper suggests a combination of legislative and digitalization measures for developing successful counter-offshore tax evasion strategies.

\subsection{Purpose of the Study}

The study's purpose of this article was to explore the challenges in curbing offshore tax evasion and analyse the existing legal measures and regulations and the digital solution adopted by the United States and the United Kingdom. Malaysia to determine if Malaysia's legislation can be improved.

\subsection{Objective of the Study}

The study highlights the critical legal and technological advancements in preventing tax evasion through offshore bank accounts in the United States and the United Kingdom and recent growth to assess the effectiveness of these attempts for change in Malaysia's tax framework. The investigation demonstrated the more aggressive techniques used by the United States and the United Kingdom to combat crime, which may be used locally to alter tax laws. The study's conclusions are expected to develop successful initiatives and substantial improvements in Malaysia's tax policy.

\subsection{Literature Review}

Globalization, technological advances, and capital mobility enabled individuals to move their wealth offshore to conceal income or profits from national tax authorities. (Antoine, 1999) Despite opening new sources of government revenues, the economy's digitalization forms many opportunities for tax evasion (Tax Justice Network 2019). This is supported by (Alm, 2021) whereby he believed that changes in technology would improve the ability of governments to decrease tax evasion, mainly by increasing the flow of information to governments. However, these changes in technology will open up new avenues by which some individuals and some firms can evade (and avoid) taxes.

The Organization for Economic and Co-Operation Development (OECD, 2021) defines tax evasion as illegal arrangements where liability to tax is hidden or ignored, i.e., the taxpayer pays less tax than he is legally obligated to pay by hiding income or information from the tax authorities. When tax evasion is widespread mainly, It may seriously harm the proper functioning of the economic system, primarily by interfering with market processes that support competition, resulting in a wide range of negative financial implications. (Argentiero et al., 2021)

It was easy to utilize offshore bank accounts for tax evasion. It involved a low risk of detection because the banking secrecy of foreign tax havens shielded tax evaders from investigations by the authorities. Tax haven refers to countries (territories) with a minimum, respectively, no taxation. These countries have non-standard, very advantageous tax regimes focused on attracting foreign capital to their environment. Many entrepreneurs seek tax havens as a target for their tax planning, whether individuals or huge company entities. Consequently, a big part of the funds initially taxed in the nation of origin of this income is spilled, resulting in a large proportion of their tax revenues being lost in their domestic government budgets. (Lénártová, 2020)

Combating tax evasion through tax havens must be more robust and effective worldwide. Around 300 world economists from more than 30 countries worldwide have declared that tax havens distort the functioning of the world economy. However, the negative consequences of their existence are much broader. These are not only economical but also social and security implications in a national and international context, which overlap, interact, multiply their effects in a negative synergic impact (Lénártová, 2020)

Offshore evasion is just one form of evasion, and it is not too surprising that it is concentrated among the rich. Government policies have an essential role in mitigating tax evasion. Increasing penalties for tax evaders has not shown to be an effective method of reducing tax evasion so far. There are limits to the penalties applied to persons conducting such crimes. If the penalties set by law are too high, judges might require a more substantial burden of proof from prosecutors, potentially leading to fewer convictions. Significant sanctions against the suppliers of tax evasion services (instead of tax evaders themselves) could help overcome this problem. If policymakers were willing to put out of business systematically, the financial institutions found facilitating evasion. The supply of evasion services would shrink, and tax evasion at the top could be reduced dramatically. In turn, a lower equilibrium level of tax evasion would make it possible, everything else equal, to raise effective tax rates and ultimately contribute to reducing inequality. Moreover, tax authorities can no longer rely on random audits to estimate the tax gap. (Argentiero et al., 2021)

These advantages are most likely to be highest in policy areas where results can only be observed at a high cost and/or when there is significant heterogeneity in responses across various agents.(OECD, 2019) 


\subsection{Methodology}

The methodology applied in this paper will be a library-based doctrinal study and comparative legal analysis, which will be done in a descriptive, analytic and prescriptive manner. In this regard, this paper analyses tax policy outcomes and other tax reform measures implemented by the United States and the United Kingdom. This study used doctrinal research to identify and determine the sources of law to analyse the legal doctrine and how it has been developed and applied (Kumar \& Malik, 2012). The doctrinal legal method is problemsolving in nature, and it is the most well-understood of legal research methods due to its links with the problem-solving approach at the heart of legal instruction (Dent, 2017). For this first step, references were made to journals, online journals, articles, and books to gain relevant, essential information and a deep understanding of the challenges and approaches in combatting offshore tax evasion in Malaysia. The study also utilised online databases such as Scopus, ProQuest, Lexis Nexis, and the Current Law Journal (CLJ) using keywords 'offshore tax evasion and 'digitalization economy.' The second step identified and analyzed legislation and regulations as primary legal sources. And lastly, the comparative approach is applied, drawing on insights gained from the United Kingdom and the United States experience to provide suggestions for optimal legislation and enforcement practice in Malaysia.

\subsection{Findings}

\subsection{Challenges face globally in preventing offshore tax evasion in a digital economy era}

Tax havens, offshore financial centers, and secrecy jurisdictions are three issues that facilitate offshore tax evasion by providing a refuge for illicit funds and preventing their discovery by national authorities. Tax havens are primarily recognized by adopting low or zero tax rates for foreign investors, and it has become a global phenomenon related to tax evasion. Reported cases show that tax havens threaten the stable development of the world economy, causing negative consequences of the worldwide scale's economic, social, security, and humanitarian nature (Lénártová, 2020). Moreover, offshore financial centers contribute to offshore tax evasion, which facilitates the offence by providing non-residents with financial services on a scale consistentwith the size and financing of their domestic economy. Most of these centers offer incentives for non-residents to invest in their economy, such as low or zero taxation, moderate or light financial regulation, banking secrecy, and anonymity(Zoromé, 2007).

It should be noted that secrecy jurisdiction also plays a vital role in facilitating offshore tax evasion. It adopts banking secrecy and structural secrecy mechanisms, which prevent disclosing information regarding income or assets to national revenue collection authorities. Secrecy jurisdictions tend to be self-governing microstates providing a combination of strict banking secrecy, favorable regulatory environments, low or zero tax rates for foreign investors, the non-disclosure of the beneficial ownership (B.O.) of companies, trusts, and foundations, and a lack of information exchange agreements with other jurisdictions (Batashev et al., 2020).

\subsection{Approaches took by the United Kingdom}

In the United Kingdom, the government's strategy for tackling offshore tax evasion was initially set out in HMRC's 2014 No Safe Havens, with a supplement issued in 2019. which is aimed to emphasize that there are no jurisdictions where U.K. taxpayers feel safe to hide their income and assets from HMRC. In addition, the Common Reporting Standard (CRS) marked 'an unprecedented step change' in its ability to tackle offshore evasion. The CRS involves an automatic and much-increased exchange of taxpayer information at the international level. All countries that had signed up for CRS were required to exchange data by the end of September 2018. As of May 2019, over 100 jurisdictions have committed to automatically exchanging financial account information under the CRS. Besides, HMRC also introduced the Requirement to Correct (RTC) rule, whereby it involved giving people time to come forward to put their affairs in order, including offshore bank account and assets (Offshore Tax Evaders: Criminal Offences, 2021)

On the other hand, offshore income, assets, and activities are regulated by section 166 of the Finance Act 2016. The Act makes it clear that any failure to declare income derived from a source in a territory outside the U.K., assets located or held in a territory outside the U.K., activities carried on entirely or mainly in a territory outside the U.K., or anything that has the effect as if it were those income, assets, or activities shall amount to the criminal offence. The provision should be read together with Section 7 and 8 of Taxes Management Act 1970, which imposes the obligation to declare income or gains exceeding $\$ 25,000$ to Her Majesty's Revenue and Custom (HMRC) (Offshore Tax Evasion: Offences Relating to Offshore Income, 2021).

\subsection{Approaches taken by the United States}

Starting in 2008, the U.S. government adopted a range of enforcement initiatives aimed at owners of offshore accounts. The carrot-andstick approach combined measures to raise the probability of detecting undeclared offshore accounts and a program that incentivizes tax evaders to disclose their foreign assets voluntarily. The enforcement initiatives on the taxation of offshore wealth increased the number of individuals reporting foreign accounts to the Internal Revenue Service by around 50,000 taxpayers. They raised the total amount of wealth disclosed by about $\$ 100$ billion. Most disclosures took place outside offshore voluntary disclosure programs by individuals (Altshuler et al., 2020). Owning offshore accounts is legal if the account's owner duly declares any interest, dividend, or capital gain earned on his individual income tax return.

At the same time, the U.S. government pursued a broader agenda to improve its access to tax-relevant information from foreign banks through bilateral information exchange agreements. The U.S. government had first signed (between 2008 to 2010 bilateral agreements about information exchange on request with six tax havens: Switzerland, Luxembourg, Liechtenstein, Malta, Monaco, and Panama. However, sufficient evidence is needed to assert the relevance of the requested information. In 2010, the U.S. Congress passed a new law, i.e., Foreign Account Tax Compliance Act (FATCA), to induce foreign banks to provide information about all accounts owned by U.S. 
taxpayers to the U.S. tax authorities. In addition, U.S. taxpayers also must file Foreign Bank and Financial Accounts (FBARs) annually if the total value of their foreign accounts exceeds $\$ 10,000$.

In addition, the U.S. government also practices Offshore Voluntary Disclosure Programs (OVDP). This is a voluntary disclosure program specifically designed for taxpayers with exposure to potential criminal liability and/or substantial civil penalties due to a willful failure to report foreign financial assets and pay all tax due in respect of those assets. OVDP is designed to provide taxpayers with exposure (1) protection from criminal liability and (2) terms for resolving their civil tax and penalty obligations.

But still, the U.S. corporate tax was eroding long whereby The global practice known as profit shifting, in which substantial multinational corporations artificially declare their earnings in tax haven nations rather than countries where they have genuine commercial activity, has been a significant cause of this erosion. By 2017, the United States was predicted to be losing $\$ 100$ billion per year due to profit shifting. And profit shifting has continued at an alarming rate.

\subsection{Approaches took by Malaysia}

In Malaysia, tax evasion offence as stipulated by Section 114 (INCOME TAX ACT 1967) of Income Tax Act 1967 whereby willful and intentional evasion or assisting any other person to evade tax. Is subject to RM1,000 to RM20,000 fine or imprisonment (not exceeding three years) or both and $300 \%$ of the tax undercharged. This is supported by Public Ruling No. 8/2000.

Offshore tax evasion is no longer easy with the Organisation for Economic Co-operation and Development's (OECD) Common Reporting Standard (CRS). Malaysia is one of more than 100 participating countries. Malaysia has committed to exchanging the CRS information from 2018 and receiving financial account information on Malaysian residents from other countries' tax authorities. This will help ensure that residents with financial accounts in other countries comply with their domestic tax laws and act as a deterrent to tax evasion. CRS obligations are imposed on Malaysian Financial Institutions (MYFIs) through the operation of the Income Tax (Automatic Exchange of Financial Account Information) Rules 2016 (CRS Rules), Income Tax (Automatic Exchange of Financial Account Information) (Amendment) Rules 2017 (CRS (Amendment) Rules 2017) and Labuan Business Activity (Automatic Exchange of Financial Account Information) Regulations 2018 (CRS Regulations)(Lembaga Hasil Dalam Negeri, 2021).

However, unlike many Western countries, Malaysia applies a territorial tax system instead of worldwide taxation, which means that foreign-sourced income is not subject to income tax in Malaysia. In other words, a person's income derived from sources outside Malaysia and received in Malaysia is tax-exempt. Moreover, individuals can open accounts with any licensed banks, including offshore accounts under the purview of Bank Negara Malaysia, and enjoy tax exemption. However, such accounts must go through the due diligence process under the Anti-Money Laundering, Terrorism Financing and Proceeds of Activities Act (Amla) and related legislation to prevent illicit finance activities.

\subsection{Analysis and Discussion}

The library-based research shows that both the United States and the United Kingdom have taken advanced approaches and initiatives in tackling offshore tax evasion among companies and individuals. Tax evasion is no longer simply a national crime committed within national borders but a transnational crime necessitating international cooperation. Offshore tax evasion poses a significant threat to worldwide revenues. The fact that Malaysia adopts a territorial tax system opens the door for tax evaders who seek to hide their wealth and evade taxes. However, it should be noted that having an offshore account or asset abroad does not necessarily show tax evasion as it is not expressly prohibited in Malaysia. It is immoral conduct but not illegal until evasion is proven under section 114 of the Income Tax Act 1967. It is difficult to prosecute offences relating to offshore shell companies due to their decentralized nature and highly mobile. Recent research on tax policies in countries has demonstrated that the choice of many structural dimensions of tax systems, including enforcement features, is quite sensitive to political considerations (Alm, 2021). Enforcement and financial regulation policies should be intertwined to get the best result.

What is needed is an administratively workable mechanism for closing gaps in the law that enable high-income individuals and corporations to avoid paying taxesor expenses that result in income that is not taxed or is taxed at a reduced rate in another country. For example, implementing digital audit is a crucial mechanism for simultaneously achieving the three goals stated in part 2.0. Under the initiative, overall audit rates would not increase for taxpayers earning less than $\$ 400,000$ relative to recent years. With audits targeted more effectively because of better information reporting, regular, honest taxpayers would be audited less often. They would have more confidence that others are not getting away with cheating while they pay full freight.

\subsection{Conclusion}

This research aimed to identify and analyze applicable legislation and other approaches of the United States and the United Kingdom, in comparison with Malaysia, towards improving Malaysia's legislation and approaches used to combat tax evasion. Appropriate literature, legal definitions, applicable legislation, reports published by relevant organizations, and scholarly articles were studied. The solution to the research question can best be described by analysing the legislation and approaches of both countries.

The primary and secondary data analysis findings lead to identifying a few critical points for the tax authority to consider. Firstly, to convert the local tax system from territorial to worldwide taxation. This allows offshore assets to be taxed towards closing the gap for wealthy people and corporations from escaping paying tax. Specific guidelines in managing a foreign account are also needed, such as imposing liability on offshore tax owners to declare their assets upon reaching the required limit. Secondly, to ensure effective running in managing a foreign account, establish a special division to coordinate foreign account taxation as the task becomes bigger and bigger 
every day. There must be a well-trained workforce in handling the cases. Thirdly, to implement a more vigorous attitude towards prosecuting tax evaders. This may lead to additional investigators and prosecutors in the Inland Revenue Board with the necessary knowledge and skills to achieve a successful conviction in tax evasion or tax fraud.

The key points identified can be corroborated by the proof found in this study. However, should the Legislature add these critical points to one of the acts mentioned above, the extent and success thereof in prosecutions will only be measurable in a minimum of five years. These initiatives advance various recommendations to improve international policy coordination, increase transparency and reporting, and establish clear sanctions. The increase in foreign account reporting reflected an increase in tax compliance. Practical implementation of modern approaches will allow regulating the volumes of the offshore activities for making more justified decisions on the imp rovement of the tax policy at various levels of management.

Next, implementing a robust minimum tax on overseas profits and removing specific provisions that can incentivize investment overseas. Policies and institutions that have previously functioned may no longer fit Malaysia's next stage of growth, with a fresh set of policies and institutions necessary at greater levels of income and development. Malaysia's policies that enabled it to effectively transition from low- to middle-income status must be modified to address the difficulties it would confront in the future. Factor accumulation was a crucial engine of Malaysia's progress at an earlier period of its history. As it makes the shift, it will need to rely on knowledge-intensive and productivity-driven growth to the technological frontier and greater emphasis on achieving inclusive and sustainable development. The analysis in this report suggests that for Malaysia to fulfill its potential, transition successfully to high-income and developed country status, and sustain equitable growth beyond that point, reforms are needed in some areas, including modernizing institutions.

\section{Paper Contribution to Related Field of Study}

The authors hope that this paper will contribute to academic discussion on strengthening offshore tax evasion legal framework in Malaysia. The study is significant for the Malaysian tax system to enhance administration efficiency in curbing tax evasion and improving revenue collection.

\section{Future Research}

This legal research can be further explored by applying qualitative method

\section{References}

Alm, J. (2021). Tax evasion, technology, and inequality. Economics of Governance, 22(4), 321-343.

Altshuler, R., Guyton, J., Hines, J., Hoopes, J., Larsen, C., Lederman, L., Miller, J., Rupert, L., Saez, E., Strang, W., Turk, A., Yagan, D., Zucman, G., Johannesen, N.,Langetieg, P., Reck, D., Risch, M., \& Slemrod, J. (2020). Taxing Hidden Wealth: The Consequences of US Enforcement Initiatives on Evasive Foreign Accounts $†$ American Economic Journal: Economic Policy, 12(3), 312-346.

Antoine, R. M. B. (1999). The Protection of Offshore Confidentiality: Policy Implications and Legal Trends. Journal of Financial Crime, 7(1), 9-25.

Argentiero, A., Casal, S., Mittone, L.,\& Morreale, A. (2021). Tax evasion and inequality: some theoretical and empirical insights. In Economics of Governance (Vol. 22,Issue 4, pp. 309-320).

Batashev, R. V., Nikonovich, S. L., Kalafatov, E. A., Polezharova, L. V., Mironova, E. A., \& Kovalevskaia, N. V. (2020). Indicators of tax evasion: Dynamics and transformation. Journal of Advanced Research in Dynamical and Control Systems, 12(3 Special Issue).

Countries Archive - Tax Justice Network. (n.d.). Retrieved November 25, 2021, from https://taxjustice.net/country-profiles/

Dent, C. (2017). A Law Student-Oriented Taxonomy for Research in Law. Victoria University of Wellington Law Review, 48(2), 371. INCOME TAX ACT 1967.

Kumar, S., \& Malik, I. (2012). Singhal and Malik | PDF | Qualitative Research | Survey Methodology. Educational Research Journal, 2(7), $252-256$.

Lembaga Hasil Dalam Negeri. (2021). https://www.hasil.gov.my/bt_goindex.php?bt_kump=6\&bt_skum=2\&bt_posi=1\&bt_unit=2\&bt_sequ=1

Lénártová, G. (2020). The Economic and Social Consequences of Tax Havens in the World. Current Problems of the Corporate Sector, 83.

OECD. (2019). "Using digital technologies to improve the design and enforcement of public policies", OECD Digital Economy Papers." OECD Publishing

OECD. (2021). Glossary of Tax Terms. https://www.oecd.org/ctp/glossaryoftaxterms.htm

Offshore tax evaders: Criminal Offences. (2021). Lexis Nexis. https://www.lexisnexis.co.uk/legal/guidance/offshore-tax-evaders-criminal-offences

Offshore tax evasion: offences relating to offshore income. (2021). HM Revenue and Customs. https://www.gov.uk/guidance/offshore-tax-evasion-offences-relating-tooffshore-income

S.Hanion, \& Galen, H. (2021). Addressing Tax System Failings That Favor Billionaires and Corporations - Center for American Progress https://www.americanprogress.org/article/addressing-tax-system-failings-favor-billionaires-corporations/ 
Storm, A., Africa, S., Coetzee, K., \& Africa, S. (2018). Towards Improving South Africa's Legislation On Tax Evasion : A Comparison. The Journal of Applied Business Research, 34(1), 151-169.

Zoromé, A. (2007). Concept of Offshore Financial Centers: In Search of an Operational Definition; Ahmed Zoromé; IMF Working Paper 07/87; April 1, 2007. 